\begin{tabular}{|l|l|l|}
\hline GOMAL UNIVERSITY \\
JOURNAL OF RESEARCH
\end{tabular}

\title{
AN ANALYSIS OF ECONOMIC FACTORS INFLUENCING REPATRIATION OF AFGHAN REFUGEES FROM PAKISTAN
}

\author{
Ubaid Ur Rehman', Syed Mudasser Abbas ${ }^{2}$ \& Alamgeer Khan ${ }^{3}$ \\ ${ }^{1}$ School of Social Sciences, The Royal Holloway University of London, UNITED KINGDOM \\ ${ }^{2}$ School of Management, Huazhong University of Science and Technology, CHINA \\ ${ }^{3}$ Department of Rural Sociology, The University of Agriculture, Peshawar
}

\begin{tabular}{|c|c|}
\hline & \\
\hline $\begin{array}{l}\text { Keyw } \\
\text { Analysi } \\
\text { Factors } \\
\text { Repatri } \\
\text { Refuge }\end{array}$ & \multirow{2}{*}{$\begin{array}{l}\text { Pakistan has been hosting Afghan refugees for almost four decades. These } \\
\text { refugees are a burden on resources of country, hence Pakistan introduced } \\
\text { repatriation of refugees with assistance of humanitarian organizations, } \\
\text { but desired success not yet achieved. This study focused on "An analysis } \\
\text { of economic factors influencing repatriation of the Afghan refugees from } \\
\text { Pakistan", therefore, utilized cross-sectional design to measure association } \\
\text { between economic factors and expatriation. Study applied quantitative } \\
\text { survey method to collect data through questionnaire. The simple random } \\
\text { technique used to approach samples in population. Variables measured } \\
\text { by the items selected from four different instruments. Data were analyzed } \\
\text { with regression using SmartPLS. The results explored that productivity, } \\
\text { labour market integration and access to shelter as indicators of economic } \\
\text { factors for Afghan refugees in Pakistan are significantly associated with } \\
\text { expatriation in presence of the mediating variable (economic well-being). } \\
\text { Hence, a pull force of economic factors in Pakistan attracts them to stay } \\
\text { in host country and avoid repatriation to homeland. } \\
\text { (c) \$ \& \& } 2020 \text { Gomal University Journal of Research }\end{array}$} \\
\hline $\begin{array}{l}\text { Article History: } \\
\text { Date of Submission: } \\
\text { 03-12-2020 } \\
\text { Date of Acceptance: } \\
\text { 16-03-2021 } \\
\text { Date of Publication: }\end{array}$ & \\
\hline Corresponding Author & Ubaid Ur Rehman: humanitarian05@yahoo.com \\
\hline DOl & \\
\hline
\end{tabular}

\section{INTRODUCTION}

The former Soviet Union entered Afghanistan in 1979 that forced millions of Afghans to flee their country. The nearest and easiest destinations were Pakistan and Iran due to geographical positions, cultural compatibility and religious affiliation. In Pakistan, they received prima facia refugee status. They arrived due to the insecurity, poor political conditions and struggling economic structure in Afghanistan. Pakistan was a haven for them (Naseh, Potocky \& Stuart, 2018). They mostly entered Khyber Pakhtunkhwa (KP) and Baluchistan. Initially, Pakistan opened its borders to the refugees without any legal requirements for entry but later introduced policies to control increasing numbers of Afghan refugees. Policy change was probably associated with improving condition in Afghanistan 
after Soviet Union leave its territory. To motivate and encourage Afghan refugees to repatriation to their homeland. Repatriation refers to "the return from a foreign country to one's homeland after a certain time". It is also the legal process of regaining citizenship through the return. It includes refugees and people that worked outside their country (Kulkarni, Hall \& Valk, 2010). It also includes people who forced to leave their own country, so later generations of migrants living away from homeland as refugees for a long time (Hyndman \& Giles, 2016; Long, 2013; King, Christou, \& Levitt, 2015).

In short, repatriation is a process that ends the expatriation of refugees in host country. The United Nations High Commissioner for Refugees (UNHCR) solutions for ending displacement identify three ways: repatriation to the country of origin, resettlement in a third country and integration in the host country. Repatriation looks like the most decent solution for refugees because resettlement depends on the conditions and regulations of the third country and the country of asylum may not allow smooth integration (UNHCR, 2017). In contrast, expatriation refers to the settlement of the migrants/refugees in another country other than the native country. In this context, for Afghan refugees, repatriation would be considered the most common solution. It is worth mentioning that repatriation is sometimes enforced by the host country when it is safe to return to the home country (Jacobsen 2005). The formal return of the Afghan refugees from the Pakistan started in 1993 (Columbia.edu, 2020). A tripartite commission was formed between Pakistan, Afghanistan and UNHCR to enhance the organized return of Afghan refugees. By the next few years, the emergence of the Taliban government brought a new wave of destabilization in the country due to conflicts and fights hence many Afghans had to flee the country again. Furthermore, the US-led attack on the Afghanistan deteriorated conditions even more that had increased the number of refugees in Pakistan.

At this stage, UNHCR and Pakistan formalized an agreement to screen Afghan refugees to detect any new arrivals as a result of the US-led war, but agreement never implemented. In 2003 Pakistan issued identity cards to Afghan refugees to ensure their legalized stay and also introduced a plan of repatriation after a tripartite agreement with UNHCR and Afghanistan. This process was initially extended to 2009 while later to end of 2015 because Afghanistan was still unstable due to the presence of American troops (Columbia.edu, 2020). The US-led war ended in 2014 after the official announcement but still, a large number of Afghans continued to live with status of refugees (Naseh et al., 2018). The reasons could be ongoing conflicts in Afghanistan in insecurity, limited resources and poverty-stricken home areas (hrw.org, 2020). To enhance repatriation, UN high commissioner initially announced grants that were later doubled to motivate refugees for repatriation. Reports identified that some refugees repatriated to get cash grants because soon after receiving grants they illegally migrated back to Pakistan. Possibly because majority of Afghans have their concerns about basic needs, vulnerabilities and security issues in repatriation (UNHCR, 2016). Also, time spent in Pakistan has given them cultural cohesion and social integration thus leaving Pakistan would not be easy.

It is reported that 74\% of Afghan refugees were born in Pakistan and 90\% moved to Pakistan before 1985. 50\% of these households live in Camps while the rest are predominantly residents of urban areas. Pakistan is still hosting 1.5 million documented and almost one million undocumented the Afghan refugees but since 2002, 4,378,058 Afghan refugees have repatriated from Pakistan with UNHCR's assistance (Amnesty international, 2016). In the last ten years, Afghanistan is one of the major recipients of return migrants on globe. One out of three was a return migrant in Afghanistan in 2011 but the living conditions of return migrants to Afghanistan is still under-researched area (Majidi 2017; Loschmann, Parsons \& Siegel, 2015). A combined report by World Bank and UNHCR explores that Afghan return migrants to Afghanistan in the period of 2014 to 2017 were financially 
extremely backward with numerous economic problems as compared to their stay in Pakistan. They were also found with the higher unemployment, instability in jobs and its availability. It is worth mentioning that only economic conditions may not serve as cause of refuge because other factors play their role in its articulation. But refugees return to a place with the unavailability of means of survival and income generation opportunities discourage their intentions of return. GDP per capita in Afghanistan's is \$634 US Dollars, in contrast to the Pakistan's \$1317 US Dollars (World Bank, 2015).

Additionally, the relations between Pakistan and Afghanistan mostly remained problematic due to blames of destabilization against one another while the withdrawal of US forces from Afghanistan ensured political cover for Pakistan to restart repatriation of Afghan refugees to their home country. For returnees, the availability of consistent and sustainable economic opportunities in Afghanistan would play vital role in their successful repatriation. Opportunities that could enable them to utilize their potential, integrate into the labour market along with immediate access shelter. Hence a place where economic well-being is secured would attract returnees. It is revealed that refugees after return are facing troubles in Afghanistan than in Pakistan. They struggle to get jobs due to poor economic conditions and lack of peace and stability in the country. Thus, this study is designed to highlight economic factors in Pakistan that are pulling Afghan refugees. In this regard, this study explore productivity, labour market integration and access to property/shelter of Afghan refugee in Pakistan.

\section{Theory in Focus}

Push and pull theory are one of the major works on migrant populations. This theory states that "migrants mainly focus on improvement of their livelihood; thus, they judge adverse socio-economic conditions against improved livelihood. There is a pull force in the improvement and push force in adverse conditions. The overall effect of pull and push forces articulate migration of the population". There could be multiple factors that may attract people to an area or compel them to stay in it. The theory highlights reasons for migration because people concentrate on improved living condition through migration. The factors that attract migrants to improving their living conditions in inflow areas is result of pull force and factors that repel migrants due to unfavorable conditions of outflow areas act as a thrust for floating population. Population migration is accomplished over combined effect of thrust of outflow areas and a pull force of inflow areas (Pan, 2019). We believe that return migrants do take into account pull and push factors to ensure economic security. They consider factors at the host and home country, in case inflow, is stronger at home country then host country becomes an area of outflow hence they would accomplish return migration. But in case of inflow is stronger at host country then home country becomes outflow area which means refugees would not repatriate. Thus, current study is utilizing this theory to explore pull factors for Afghan refugees in Pakistan.

\section{Rationale of Study}

This study focuses on economic factors in repatriation of Afghan refugees in Pakistan. The united nations (UN) initiated a repatriation program to attract Afghan refugees back to Afghanistan and its application was partially forced in Pakistan to make it successful. Also, financial incentives were offered to refugees in Pakistan, but desired results were not achieved. It shows that Afghan refugees are enjoying their lives in Pakistan possibly because of secure economic conditions in the country. Thus, this study is designed to address those economic factors that are pulling Afghan refugees into Pakistan.

\section{LITERATURE REVIEW}

Studies on repatriation explored role of different factors and their influence on return migration. A quantitative study on Afghan refugees reports that living standards or conditions of shelters are the 
factors influencing repatriation (Naseh et al., 2018). For instance, good living conditions or shelters in host country than home country discourage repatriation. Review from quantitative data explored that economic instability, unemployment, destabilization in area and inability to reclaim property are the factors that hinder repatriation (Thiel \& Gillan, 2010). A qualitative study also explored that returning Afghan refugees are caught in the complex political and military environment. This study addressed four variables that included the number of returning refugees and displaced persons, the military and public stability, infrastructural conditions and the agricultural productivity. It further explored that Afghanistan suffered the greatest infrastructural damage, the highest percentage of land abandonment and intensive fighting in region negatively affecting repatriation (wood, 1989). Other qualitative studies (Badalič, 2019; Hiegemann, 2018) reported that repatriation is forced by the Pakistani government by encouraging anti-refugee sentiment in local people, and also physical, legal and material safety of Afghans was compromised in process of repatriation. They also reported that refugees are pressured to leave the host country in-spite of unfavorable conditions in the home country.

A report from the online website regarding the repatriation of Afghan refugees highlighted many listed factors both in Pakistan and Afghanistan that are acting as barriers in process of repatriation. Those factors in Pakistan include better economic conditions, established business, better social services and better educational opportunities and integration in local culture, while in Afghanistan factors like lack of peace and stability, bad law and order, violation of human rights, lack of economic opportunities, no land/property, presence of allied forces and lack of social services (reliefweb.int, 2016). IOM in its research on repatriated Afghan refugees explored that repatriation from Pakistan was inspire by push factors like returning home (39\%), economic factors (24\%), fear of deportation (16\%) and pressure from the host community (11\%). Only 24\% expressed that economic factors are pushing them to repatriate. A study on repatriation of Afghan refugees from Pakistan reported that repatriation requires overall general improvement in conditions of home country. It also explored that the pull factors need to be stronger than push factors in the host country. The study further reported that the situation in Afghanistan was not encouraging to welcome numerous returnees' home which means that those who are returning or already returned were forced to do so (Hatam, 2019).

Khan (2016) analyzed role of consultation and consent of Afghan refugees in process of repatriation from Pakistan. He studied the tripartite repatriation program of UNHCR, Pakistan and Afghanistan hence explore that Afghan refugees were ignored in repatriation process because their participation and consent were not counted while executing repatriation plans. It is suggested that participation, voices and consent of Afghan refugees in repatriation may improve process. A study on repatriation of Afghan refugees reported the concept of split return at a time of repatriation found in Afghans. Split is considered as a measure and opportunity for repatriation. This kind of repatriation may help in the sustainability of the household economic upon return to the home country (Harpviken, 2014). A research article elaborated that repatriation of Afghan refugees from Pakistan could only be successful if root causes are eliminated in the first place, for this purpose UNHCR, the Pakistan government and Afghanistan government has to focus on these causes initially and then motivate and inspire repatriation (Hatam, 2018). Report from strategic studies Pakistan on Afghan refugees explored that Afghan refugees are reluctant to repatriate. Reluctance is due to prevailing conditions in Afghanistan, loke, Afghan government-initiated shelter projects for returnees but no satisfactory progress was made. Hence those who are still refugees are reluctant to repatriate from Pakistan to their homeland (Khan, 2017). Variations in economic factors and number of migrants for period of 1950 to 2010. It suggests that changes in migrant populations are correlated to changes in economic factors. 


\section{Gap in Literature}

Literature regarding repatriation of Afghan refugees explored numerous dimensions but a concrete study on economic factors and their influence on the repatriation of Afghan refugees in Pakistan cannot found as far as our awareness is concerned. Though there are studies on the repatriation of Afghan refugees in other countries, those studies cannot be replicated into the Pakistani context because of the social, economic and cultural difference. Therefore, this study is designed to address this gap in the literature. The study would not only bring an addition to knowledge and literature but would also crystalize the economic factors in the wider framework particularly within Pakistani context.

\section{Conceptual Framework}

The economic factors can be numerous and may vary in nature from place to place and time to time. Regarding this study economic factors are those aspects that are directly related to income, work, standard of life, accessibility and availability of shelter and stability in terms of economic position. Consequently, this study included productivity, labour market integration, access to the shelter as indicators for measuring the economic factors. The economic well- being included as the mediating factors.

\section{Repatriation Measured Through Expatriation Status}

The repatriation refers to the return of refugees to their homeland. In the context of this study, we consider repatriation as a process that ends the expatriation of Afghan refugees in Pakistan. In this research, we would use the term "expatriation" as the dependent variable to the economic factors. Hence ending expatriation would mean successful repatriation while sustaining expatriation would mean unsuccessful repatriation. Expatriation indicates a settlement of migrant/refugees in another country other than the country of the origin. Regarding Afghan refugee's expatriation means the settlement of Afghan refugees in Pakistan. Hence the preference for the expatriation would mean rejecting repatriation. So, expatriation would help to measure repatriation as an ending process of expatriation.

\section{Productivity}

Productivity is key to performance of every economy. It is usually calculated and expressed as the measure of value of economic output produced by each worker or by each hour worked. The ability to improve standards of living depends almost entirely on an economy's ability to raise its output per worker overtime. This definition is highlighting that productivity is related to economic output. In the context of Afghan refugees in Pakistan, this study uses the term productivity for the economic output of every Afghan refugee, as standard of living in Pakistan is dependent on economic output per work overtime. Productivity in measured over work and income status (Migrationwatchuk, 2020).

\section{Labour Market Integration}

The labour market integration, defined as holding a permanent full-time job, provides the sound economic basis for family or its formation. This definition explores labour market integration is the availability and consistency of job for person in host country that leads to sound economic position. In this research labour market integration of Afghan refugees mean availability and consistency of job for them in Pakistan. This is measured through the job history and work appreciation (Schmitt, 2012).

\section{Immediate Access to Property or Shelter}

The right to adequate housing is one of the economic, social and cultural rights to have gained increasing attention and promotion, not only from human rights bodies but from United Nations 
Centre for Human Settlements (Habitat). Adequate housing is universally viewed as one of the most basic human needs (UN.org). Access to shelter for Afghan refugees in Pakistan is paid therefore it needs economic resources to avail access to shelter or property. Hence in context of this research access to shelter means ability of a person to get paid access to shelter over rent or buying. It means that access to shelter is based on economic resources so it is included in economic factors in this study.

\section{Economic Well-Being}

Economic well-being refers to ability to sustain financial security in present and future. as having present and future financial security. Ability to avail basic needs with consistency while sustaining them in future with the capability to absorb financial shocks (CSWE.org, 2020). The economic wellbeing refers to ability of Afghan refugees to ascertain consistency in production, labour market integration and access to shelter while sustaining them in future with capability to absorb financial shocks.

\section{Figure 1}

\section{Diagram of Variables}

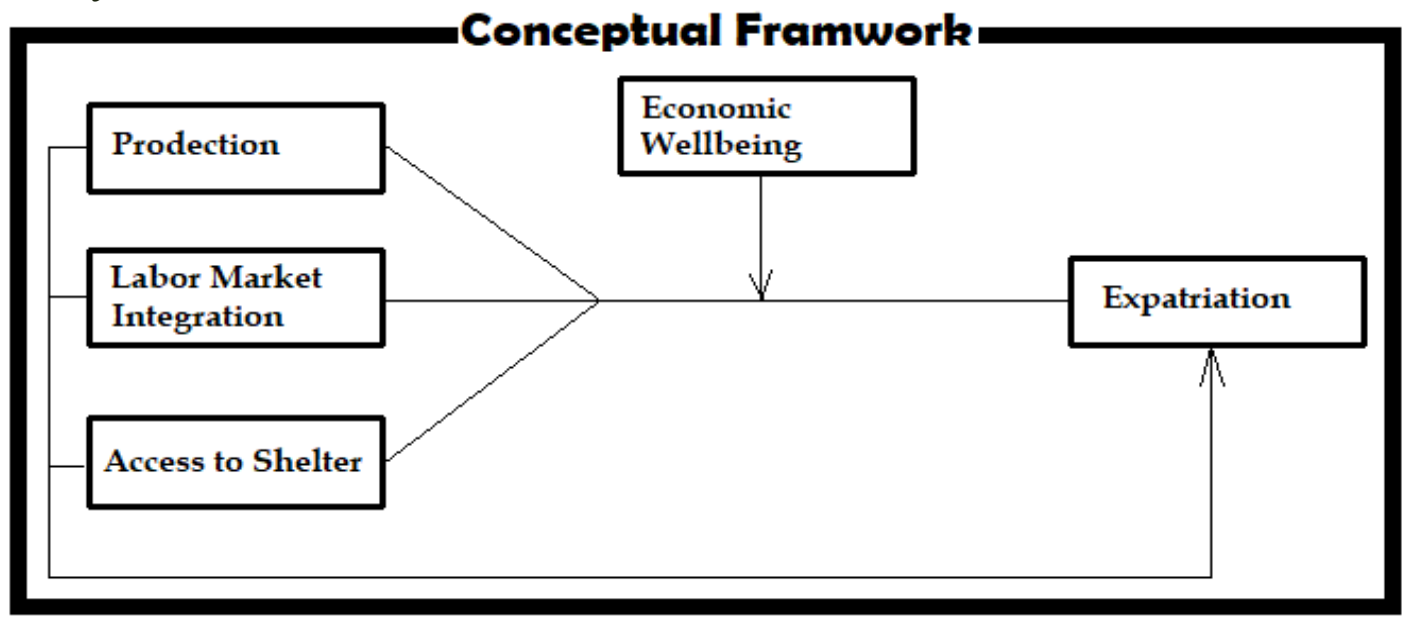

\section{Objectives of Study}

1. To examine the demographic characteristics of the Afghan refugees those who are living in Pakistan.

2. To find out the pulling influence of economic factors on the repatriation of Afghan refugees in Pakistan.

3. To measure the association between economic factors and repatriation in the presence of mediating factor.

4. To suggest measures to enhance the repatriation process from the results of the present research study.

\section{Hypothesis}

Main Hypothesis: Stronger the influence of economic factors thus weaker will be the process of the repatriation

H1. The productivity is positively and significantly associated with the expatriation H2. The Labour market integration is positively associated with the expatriation 
H3. The Access to shelter is positively and significantly associated with expatriation H4. There is positive and significant association amid economic well-being and the expatriation H5a. Productivity in the presence of a mediator is significantly associated with the expatriation H5b. Labour market integration through mediator is significantly associated with expatriation $\mathrm{H} 5 \mathrm{c}$. Access to shelter in the presence of a mediator is significantly associated with expatriation

\section{MATERIALS AND METHODS}

This study adopted a cross-sectional design because the study was conducted at a certain point in time. The nature of the study was quantitative hence utilized the survey method with the help of a questionnaire to collect data. The study was conducted in Peshawar city to investigate repatriation of Afghan refugees, coverage of the entire district in the context of this research was not possible thus two locations (a refugee's camp (Kachha Gari) and a settled area (Shah Colony) were randomly selected. These two different locations based on the living standard were selected to highlight the difference between the perception of refugees for repatriation concerning their living standard. In this regard, at the time of the data collection refugees in the camp were alert by the authorities to repatriate.

\section{Sample Size}

Population details of the two locations were collected from the UNHCR office in the district where 4530 individuals were identified. All individuals were not included in data collection because such huge data may generate problems in the organization and analysis of data. Therefore, the Sekaran sample size calculation procedure was adopted to specify a sample size of 357(Sekaran, 2003). To access the sample simple random sampling approach was adopted, this sampling is one of the types of probability sampling where each unit in the population has an equal chance of selection. Sample allocation for the two locations was carried out through the formula given below. Consequently, each of the location Kacha Gari and Shah Colony were allocated with the sample size 153 and 203 respectively.

$\mathrm{ni}=(\mathrm{Ni} / \mathrm{N}) \times \mathrm{n}$, where, $\mathrm{ni}=$ Total sample, $\mathrm{n}=$ Total sample, $\mathrm{Ni}=$ population in each location $\& \mathrm{~N}=$ population.

Table 1

Sample Size Allocation

\begin{tabular}{lcc}
\hline Location & Population size & Sample size \\
\hline Kacha Gari & 1948 & 154 \\
Shah Colony & 2582 & 203 \\
\hline Total & 4530 & 357 \\
\hline
\end{tabular}

\section{Measurement and Instrumentation}

The data were collected with the help of the questionnaire regarding dependent (expatriation) and independent (Productivity, labor market integration and access to property/shelter) and mediating (economic well-being) variables. Measurement of these variables was ensured through selected items from instruments like productivity questionnaire, rapid house assessment, subjective welfare and well-being and expatriate adjustment. Items from each instrument were included according to the need of study. All instruments were highly reliable because they were designed for international studies but to ensure reliability of all items in a single questionnaire for a small-scale study: a pilot study was conducted where data were collected from 56 individuals thus tested for reliability which was reported as 0.82. After getting such decent reliability score questionnaire was used for full-scale study. 


\section{Data Collection and Analysis}

Data collection from respondents were carried out with the help of a questionnaire. After collection of data analysis was conducted with SmartPLS software. This software uses regression to measure the association between dependent and independent variables. In this connection, it also measured the impact of the mediating variable on the relation of the dependent and independent variables. Therefore, the measurement model evaluation (MME) and structural model evaluation (SME) were conducted.

\section{RESULTS OF STUDY}

Demographic characteristics of respondents revealed that $80 \%$ were in the age group 15-45, 79\% were married, mostly illiterate, majority were Pashtuns and working in different sectors like daily wage labours, weaving, driving, business, shopkeeping. with income ranges from 5000 to 30000 per month. About repatriation to Afghanistan, only $32 \%$ had intentions to repatriate: amongst them majority were living in refugees camp while very few of those living in settled area had intentions to repatriate.

\section{Measurement Model}

PLS-SEM carried out a model evaluation in two ways i.e., outer model evaluation also known as measurement model evaluation (MME) and inner model evaluation also known as structural model evaluation (SME). Hence outer model and inner model evaluation were performed (Hair et al., 2017). In the outer model evaluation, the reliability and discriminant validity were measured in the table 2.

Table 2

Composite Reliability

\begin{tabular}{lc}
\hline \multicolumn{1}{c}{ Items } & Reliability \\
\hline Economic well-being & 0.897 \\
Expatriation & 0.864 \\
Labor market integration & 0.892 \\
Productivity & 0.910 \\
\hline Access to Shelter & 0.918 \\
\hline
\end{tabular}

\section{Discriminant Validity}

According to Fornell and Larcker's (1981) criterion, all constructs fulfilled the DV criteria in Table No. 3. Discriminant validity is established by evidence that measures of constructs that theoretically should not be related highly to each other are, in fact, not found to be correlated highly to each other.

Table 3

Fornell and Larcker Criterion: Discriminant Validity

\begin{tabular}{cccccc}
\hline \multicolumn{2}{l}{ Economic Well-being } & Labour Market & Productivity & Expatriation & Shelter \\
\hline $\mathrm{E}$ & 0.749 & & & & \\
$\mathrm{~L}$ & 0.807 & 0.707 & & & \\
$\mathrm{P}$ & 0.947 & 0.916 & 0.756 & & \\
$\mathrm{R}$ & 0.941 & 0.936 & 0.989 & 0.772 & 0.788 \\
\hline $\mathrm{S}$ & 0.964 & 0.853 & 0.972 & 0.967 & \\
\hline
\end{tabular}




\section{Structural Model Evaluation}

SME comprised significance of the structural model, R2 value (coefficient of determination), f2 (effect size) and Q2 value (predictive relevance) (Hair, Ringle \& Sarstedt, 2011). To evaluate model's predictive power, Sarkar, Echambadi and Cavusgil (2001) proposed to use explained variance (R2) measure. Our study show $93.9 \%$ and $98.8 \%$ of R2 variance in economic well-being and expatriation respectively. Hence it was a strong predictor in context of current research. $\mathrm{f} 2$ evaluates the impact of the exogenous construct. Its values indicate largely, medium, small and no impact within range of $0.35,0.15,0.02$ and less than 0.02 respectively, (Hair et al., 2017). The finding of this study explored that productivity and labour market integration had a medium impact on economic wellbeing while access to shelter had a large impact on economic well-being. Similarly, productivity and labour market had had a medium impact on expatriation while expatriation had a large impact on expatriation.

\section{Table 4}

Structural Model Evaluation

\begin{tabular}{|c|c|c|c|c|}
\hline Construct & R2 & Q2 & f 2 & $\mathrm{p}-\mathrm{v}$ \\
\hline Economic Wellbeing & 0.939 & 0.271 & & \\
\hline Expatriation & 0.988 & 0.276 & & \\
\hline Productivity-Economic well- being & & & 0.160 & 0.000 \\
\hline $\begin{array}{l}\text { Labor market integration- } \\
\text { Economic well-being }\end{array}$ & & & 0.170 & 0.001 \\
\hline $\begin{array}{l}\text { Access to shelter Economic } \\
\text { Well-being }\end{array}$ & & & 0.367 & 0.014 \\
\hline Productivity-Expatriation & & & 0.334 & 0.012 \\
\hline $\begin{array}{l}\text { Labor market integration } \\
\text { Expatriation }\end{array}$ & & & 0.197 & 0.003 \\
\hline Access to shelter-Expatriation & & & 0.169 & 0.000 \\
\hline
\end{tabular}

\section{Figure 2}

Full Diagram of all constructs and their Relations

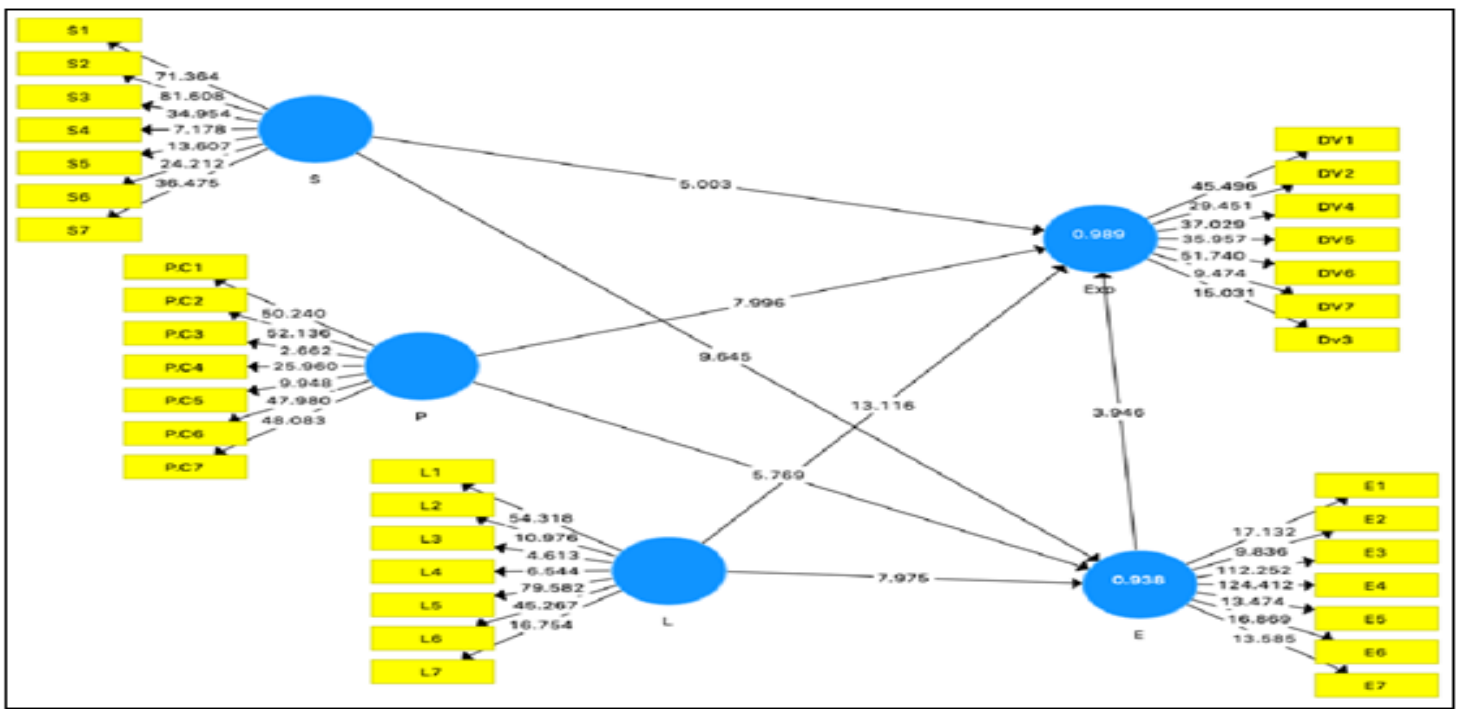


Q2 measures the predictive relevance of the model. A positive value for Q2 indicates the predictive relevance of the model. Our results explored positive values for expatriation and economic wellbeing as $0.271 \& 0.276$ respectively. This procedure explains that theoretical model has predictive relevance (Hair et al., 2017). All the results have shown a theoretical explanation for the proposed model.

\section{Hypotheses Assessment}

The aggregate scores of the constructs can affect path coefficients. We applied the bias-corrected and accelerated (BCa) bootstrap confidence interval to check the bias effect and added in all path coefficients (see Table 5). Therefore, to determine the path co-efficient, t-statistics and p-values for the hypotheses testing, the bootstrapping method applied at the 0.05 significance level (Hair et al., 2017).

Table 5

Hypotheses Testing and Structural Relationship Results

\begin{tabular}{|c|c|c|c|c|c|}
\hline & & $\mathrm{PC}$ & $95 \%$ CIB & $t-v$ & $\mathrm{p}-\mathrm{v}$ \\
\hline \multicolumn{6}{|c|}{ Direct Effects } \\
\hline H1 & $P->\operatorname{Exp}$ & 0.469 & 0.3960 .546 & 4.393 & 0.003 \\
\hline $\mathrm{H} 2$ & $L->\operatorname{Exp}$ & 0.259 & 0.2280 .286 & 8.246 & 0.000 \\
\hline H3 & $S->\operatorname{Exp}$ & 0.290 & 0.2180 .348 & 9.182 & 0.000 \\
\hline $\mathrm{H} 4$ & E-> Exp & 0.128 & 0.0590 .182 & 4.161 & 0.000 \\
\hline \multicolumn{6}{|c|}{ Indirect Effects } \\
\hline H5a & $P->E->E x p$ & 0.551 & 0.3580 .748 & 5.933 & 0.006 \\
\hline $\mathrm{H} 5 \mathrm{~b}$ & $\mathrm{~L}->\mathrm{E}->\operatorname{Exp}$ & 0.233 & 0.1560 .192 & 6.897 & 0.000 \\
\hline $\mathrm{H} 5 \mathrm{c}$ & S-> E-> Exp & 0.627 & 0.4540 .772 & 8.217 & 0.008 \\
\hline
\end{tabular}

Note(s): PC means path coefficient; CIB means confidence interval bias; $t-V$ means t- value; $p-V$ means p-value

This study found that productivity, labour market integration and access to the shelter had direct significant impacts on expatriation; thus, $\mathrm{H} 1 \mathrm{P} \rightarrow \operatorname{Exp}(\mathrm{p}=0.003), \mathrm{H} 2 \mathrm{~L} \rightarrow \operatorname{Exp}(\mathrm{p}=0.000)$ and $\mathrm{H}_{3}$ $\mathrm{S} \rightarrow \operatorname{Exp}(\mathrm{p}=0.000)$ were supported. Hence, H1 to H3 was found true and accepted. In this context, economic well-being also had direct impact on expatriation, $\mathrm{H}_{4} \mathrm{E} \rightarrow \mathrm{Exp}(\mathrm{p}=0.000)$ was supported. The results further explored that economic well- being as a mediator having a significant impact on the associations of productivity, labour market integration and access to shelter. Therefore, $\mathrm{H}_{5} \mathrm{P}$ $\rightarrow \mathrm{E} \rightarrow \mathrm{Exp}, \mathrm{H}_{5} \mathrm{~b} \mathrm{~L} \rightarrow \mathrm{E} \rightarrow \mathrm{Exp}$, and $\mathrm{H}_{5} \mathrm{c} \mathrm{S} \rightarrow \mathrm{E} \rightarrow$ Exp found as true and supported. Findings show that economic well-being was partially mediating the link amid productivity, labour market integration, access to shelter and expatriation. The details of hypothesis and mediations are given in tables below.

\section{Mediation Analysis}

This analysis evaluates the impact of mediating variable on relation of independent and dependent variables. In this study mediating analysis was conducted to evaluate the role of economic wellbeing on the relation of productivity and expatriation. The results explored significant total effect of productivity on expatriation ( $\mathrm{H} 1: \beta=0.469, \mathrm{t}=12.39, \mathrm{p}<.001)$. Most importantly this relation remains same after inclusion of mediating variable $(\beta=0.398, t=8.30, p<.001)$, while indirect effect amid productivity and expatriation in presence of economic well-being confirm significant relation. This means that relation amid productivity and expatriation is partially mediated by economic wellbeing. 
Furthermore, results regarding the total effect of labour market integration (L) on expatriation (Exp) revealed a significant effect $(\mathrm{H} 1: \beta=0.259, \mathrm{t}=18.24, \mathrm{p}<.001)$. This result remained significant even after the inclusion of mediating variable Economic well-being $(E))(\beta=0.289, t=16.78$, $\mathrm{p}<$.001). The indirect effect for these variables also reported a significant relation $(\beta=-0.030, t=$ $3.829, \mathrm{p}<.001)$. This means that relation between labour market integration and expatriation is partially mediated by economic well-being. Also, results about the effect of access to shelter (S) and expatriation (Exp) in presence of mediating variable (MV). The results explored the significant total effect of access to shelter on expatriation and this effect remained significant even after inclusion of mediating variable $(\mathrm{H} 1: \beta=0.290, t=9.18, p<.001)$. In the case of the indirect effect of access to the shelter on expatriation, results were also significant $(\beta=0.080, t=4.553, p<.001)$. Hence it means that relationship amid access to shelter and expatriation is partially mediated by economic well-being.

\section{Table 6}

Mediating Analysis

\begin{tabular}{|c|c|c|c|c|c|c|c|c|c|}
\hline \multicolumn{2}{|c|}{ Total Effect } & \multicolumn{2}{|c|}{ Direct Effect } & \multicolumn{3}{|c|}{ Indirect Effect } & \multirow[b]{2}{*}{$\begin{array}{l}\mathrm{t} \\
2.94\end{array}$} & \multirow[b]{2}{*}{$\begin{array}{l}\mathrm{p} \\
.000\end{array}$} & \multirow[b]{2}{*}{$\begin{array}{c}\text { BI }(95 \%) \\
0.040 \\
0.110\end{array}$} \\
\hline $\begin{array}{c}\text { Coefficient } \\
0.469\end{array}$ & $\begin{array}{l}\mathrm{p} \\
.000\end{array}$ & $\begin{array}{c}\text { Coefficient } \\
0.398\end{array}$ & $\begin{array}{l}\mathrm{p} \\
.004\end{array}$ & H: P->E->Exp & $\begin{array}{c}\text { Coefficient } \\
0.071\end{array}$ & $\begin{array}{c}\text { SD } \\
0.024\end{array}$ & & & \\
\hline 0.229 & .000 & 0.289 & .000 & $\mathrm{H}: \mathrm{L}->\mathrm{E}->\operatorname{Exp}$ & 0.030 & 0.008 & 3.829 & .000 & $\begin{array}{l}0.046 \\
0.017\end{array}$ \\
\hline 0.290 & .000 & 0.210 & .002 & H: S->E->Exp & 0.080 & 0.018 & 4.553 & .003 & $\begin{array}{l}0.032 \\
0.119\end{array}$ \\
\hline
\end{tabular}

In the light of hypothesis assessment and mediation analysis, it can be concluded that economic factors in the presence of economic well-being were positively influencing the expatriation of Afghan refugees in Pakistan. Hence it can be concluded that the main hypothesis "The stronger the influence of economic factors in host country the weaker will be process of repatriation" is true and accepted.

\section{DISCUSSION}

Economic factors play a vital role in shaping the decision of refugees regarding their return to the homeland. Demographic characteristics regarding their return to the homeland. Demographic characteristics of Afghan refugees explored majority were young. It means most of them were born in Pakistan. Hence, strong social networking and integration at birthplace could be a prominent factor in repatriation. Future research would be helpful to explore this issue in detail. Also, the intentions of Afghan refugees regarding repatriation revealed a small proportion were willing to repatriate. Amongst them, the majority were the residents of the camp while very few from the settled area. A possible reason could be the access of Pakistani authorities and the weak economic position of those refugees in the camps but, refugees in the settled area were economically strong, so they were not interested in repatriation. Hence this study aimed at exploring the influence of economic factors on repatriation. The results highlighted that economic factors were significantly influencing the repatriation of Afghan refugees in Pakistan. Parallel, results were reported by (Thiel \& Gillan, 2010) in their study where they found significant relationship amid economic factors and repatriation.

This study further explored that refugees take into account their productive ability as in Pakistan while living in expatriation their state of productivity is prominent as they are earning while in case of repatriation, they may not be as productive as in their current status. These findings were in line with report of (reliefweb.int, 2016) that found limited economic opportunities in strong association 
with failure in the repatriation process. Besides, majority of the Afghan refugees were working in different sectors according to their skills. It means that the labour market in Pakistan can integrate these Afghan refugees. This labour market integration is a source of economic stability and security in expatriation state in Pakistan while in case of repatriation there may not be any financial stability and security in homeland. They prefer to stay in Pakistan over repatriation to Afghanistan. Parallel results found by (Harpviken, 2014) in his study revealed sustainability in household economy about repatriation. Also, access to shelter in Pakistan would not be a problem of grave concern because they have consistent income due to utilization of their productive ability and integration in labour market.

This sustainable access to economic sources promotes the chances of access to shelter while in case of repatriation refugees may be in a state of confusion whether they would find shelter immediately after their repatriation or not. Thus, staying in Pakistan remains their priority over repatriation to their homeland. Similar results were reported by (Naseh et al.,2018) where they found a significant influence of access to the shelter on repatriation. Also, Afghan refugees would consider their economic well-being in the context of economic factors and repatriation. This study found that economic well-being has a significant association with the expatriation of Afghan refugees. Such results are also reported by (where he revealed. The economic well-being of the Afghan refugees encompasses their present and future state of productivity, labour market integration and access to shelter. In Pakistan economic well-being of Afghan refugees is more secure than in Afghanistan because at present Afghan refugees can generate income, integrate into the labour market and get immediate access to shelter and regarding the future, they might be feeling more secure due to the stable conditions of Pakistan. In contrast, the economic well-being of returnees to Afghanistan may not have any present and the future security which means that they could face any unexpected conditions.

Therefore, keeping in view the economic well-being: in context of prevailing economic conditions, Afghan refugees would prefer to stay in Pakistan which is strongest findings of this research. Thus, repatriation would remain unsuccessful. The reason behind the failure of repatriation highlighted by the push and pull theory of migration. In light of this theory, we would elaborate that: there are prominent and strong economic factors in Pakistan such as productivity, labour market integration, access to shelter accompanied by a broader vision of economic well-being, these factors are vastly attracting Afghan refugees towards Pakistan. In contrast, lack of economic opportunities, inability to integrate labour into market and fear of immediate access to the shelter may be repelling Afghan refugees from Afghanistan. Hence, attraction makes Pakistan an area of inflow while Afghanistan becomes an area of outflow, therefore the net result would be that Afghan refugees would sustain their expatriation and avoid repatriation. It is worth mentioning that repatriation is not solely an economic phenomenon hence there could also be political and social factors in the articulation of this process. So, future research on other factors would not only help to deepen understanding of the issue but may also find the recommendations that would help to minimize complications in repatriation.

\section{CONCLUSION}

It is concluded that economic factors influence the repatriation of Afghan refugees from Pakistan. Afghan refugees are more productive in terms of income generation and earning in their host country. Availability of a vast labour market for integrating individuals in multi-sectors enhanced job opportunities and consistency for the economic stability of Afghan refugees in Pakistan. Also, sustainability in access to the shelter with the option of free mobility brought more attraction for Afghan refugees to continue their lives in expatriation. Also, Afghan refugees were also concerned with economic well-being. In present Afghan refugees were more secure and stable economically 
while in future they expected the prevalence of security and stability in Pakistan was attracting them. In contrast, insecure and unstable conditions in Afghanistan particularly for the returnees were repelling them. So, Afghan refugees were preferring expatriation in Pakistan over repatriation to homeland. It is suggested that Job availability, economic opportunities and access to immediate shelter in Afghanistan would help in the enhancement of the Afghan refugee's repatriation from Pakistan.

\section{REFERENCES}

Badalič, V. (2019). The Reverse Exodus: The Forced Repatriation of Afghan Refugees in Pakistan. In: The War Against Civilians. Palgrave Studies in Victims and Victimology. Palgrave Macmillan, Cham. https://doi.org/10.1007/978-3-030-12406-9_10.

Fornell, C., \& Larcker, D. (1981). Evaluating Structural Equation Models with Unobservable Variables and Measurement Error. Journal of Marketing Research, 18(1), 39-50. doi: $10.2307 / 3151312$.

Hair, J. F., Hollingsworth, C. L., Randolph, A. B., \& Chong, A. Y. L. (2017). An updated and expanded assessment of PLS-SEM in information systems research. Industrial Management \& Data Systems, 117 (3), 442-458.

Hair, J. F., Ringle, C. M., \& Sarstedt, M. (2011). PLS-SEM: Indeed, a silver bullet. Journal of Marketing Theory and Practice, 19(2), 139-151.

Harpviken, K. B. (2014). Split return: Transnational household strategies in Afghan repatriation. International Migration, 52(6), 57-71.

Hatam, A. K. (2018). Repatriation of Afghan Refugees from Pakistan: A Legal Analysis. Humanities, 1(2), 39-60.

Hatam, A. K. (2019). Repatriation of Afghan Refugees from Pakistan: A Legal Analysis (Part-II). Humanities, 2(1), 1-18. http://www.columbia.edu/ kfs2110/afghans/pakistan_2.html.

https://www.columbia.edu/history of repatriation.

https://www.cswe.org.

https://www.migrationwatchuk.org/media-reports-archive/2020-7

Hyndman, J., \& Giles, W. (2016). Refugees in extended exile. New York, NY: Routledge.

Jacobsen, K. (2005). The economic life of refugees. Kumarian Press, Bloomfield

Khan, A. (2017). Protracted Afghan Refugee Situation. Strategic Studies, 37(1), 42-65.

Khan, N. (2016). Repatriation of Afghan refugees from Pakistan: Participation, consultation and consent in the resettlement process.

King, R., Christou, A., \& Levitt, P. (2015). Links to the diasporic homeland: Second generation and Ancestral 'Return' mobilities. London: Routledge.

Kulkarni. M., Hall, M. L., \& Valk, R. (2010), Employee perceptions of repatriation in an emerging economy: The Indian experience. Human Resource Management, 49: 531-548.

Long, K. (2013). The point of no return: Refugees, rights, and repatriation. Oxford: Oxford University Press.

Loschmann C, Parsons CR, Siegel M (2015) Does shelter assistance reduce poverty in Afghanistan? World Development 74:305-322

Majidi, N. (2017). From forced migration to forced returns in Afghanistan: Policy and program implementation. Migration Policy Institute,Washington https://www.migrationpolicy.org/ research/forced-migration-forced-returns- Afghanistan. Accessed 18 Dec 2017.

Naseh, M., Potocky, M., \& Stuart, P. H. (2018). Repatriation of Afghan refugees from Iran: a shelter profile study. International Journal of Humanitarian Action, 3, 13.

Pan. G., (2019) The Push-Pull Theory and Motivations of Jewish Refugees. In: A Study of Jewish Refugees in China (1933-1945). Springer, Singapore. https://doi.org/10.1007/978-981-139483-6_9. 
Sarkar, M., Echambadi, R., Cavusgil, S.T. (2001). The influence of complementarity, compatibility, and relationship capital on alliance performance. Journal of the Academy of Marketing Science. 29, 358. https://doi.org/10.1177/03079450094216

Schmitt. C., (2012). Labour Market Integration, Occupational Uncertainty, and Fertility Choices in Germany and the UK, Demographic Research, Max Planck Institute for Demographic Research, Rostock, Vol. 26, Iss. 12, pp. 253-292, http://dx.doi.org/10.4054/DemRes. 2012.26.12.

Sekaran, U. (2003) Research Methods for Business: A Skill-Building Approach. 4th Edition, John Wiley \& Sons, New York.

UNHCR (2016) Chapter 7: Solutions for refugees in the 10-point plan in action. UNHCR, Geneva, pp 184-206 http://www.unhcr.org/50a4c17f9.pdf

UNHCR. (2017). UNHCR Afghanistan Voluntary Repatriation Monthly Report, June 2017. UNHCR, Kabul https://data2.unhcr.org/en/documents/download/59085.

Wood, W. (1989). Long Time Coming: The Repatriation of Afghan Refugees. Annals of the Association of American Geographers, 79(3), 345-369. Retrieved January 27, 2021, from http://www.jstor.org/stable/2563723.

www.reliefweb.int/report/afghanistan/afghanistan-voluntary-repatriation-update- January December -2020.

www.worldbank.org/en/about/annual-report-2015 